\title{
Interpreting Medicine: Lessons From a Spanish-Language Clinic
}

\section{Benjamin P. Brown, MD}

Department of Obstetrics and Gynecology, University of Chicago Medical Center, Chicago, Illinois
Conflicts of interest: author reports none.

\section{CORRESPONDING AUTHOR}

Benjamin P. Brown, MD

Department of Obstetrics and Gynecology

University of Chicago Medical Center

5841 S. Maryland Avenue - MC 2050

Chicago, IL, 60637

benjamin.brown@uchospitals.edu

\begin{abstract}
Caring for patients is an act of interpretation: we labor to understand the significance of a particular symptom and, when we have reached a diagnosis, we convert our medical jargon into plain language for the benefit of the patient. Caring for patients of limited English proficiency-a population that needs a very literal form of interpretation-underscores this lesson. Working with predominantly Spanish-speaking patients has shown me the importance of bearing witness to patients' struggles and has brought me to realize that good physicians must work to forge a common language with all their patients, not only with those who do not speak English.
\end{abstract}

Ann Fam Med 2014;12:473-474. doi: 10.1370/afm.1661

S he was in her early twenties, dressed in a red T-shirt and maternity jeans, around 30 weeks into her first pregnancy. She smiled broadly when I breezed into the room. I sat down on the stool and opened her chart. It was halfway through intern year, and my colleagues and I had all long since memorized the standard obstetric review of systems: Any contractions? Any bleeding? Leaking clear fluid like your water has broken? Baby's moving okay?

I launched into the routine questions: "CCómo se siente hoy? ¿Contracciones? ¿Sangrado? ¿Flujo de líquido claro como si tuviera rompido la fuente? ¿El bebé está moviendo?" No, she assured me: everything was fine. We discussed the results of her glucose tolerance test (normal), talked about plans for feeding after delivery (she was still figuring on formula but was considering trying to breastfeed), and made some idle small talk about the interminable Chicago winter. I handed her discharge instructions and wished her well. "Le veremos en dos semanas." See you in 2 weeks.

Back in the resident work room, I took a sip of tea and logged into the computer. All 7 slots on my afternoon schedule were full: a couple of annual exams, a few more return obstetric visits, and a follow-up appointment for a patient who'd been treated in the ER for vaginal discharge. I scanned the scheduler's notes (the person booking the visit usually dashes off a brief sentence fragment to explain why the patient is being seen). At the end of all but one, I found the familiar designation, "SPO"_Spanish only.

Sometime around January of that year, the proportion of Spanishspeaking patients in my clinic had begun to rise precipitously while the number of English speakers dwindled. No doubt this was when it became common knowledge among the clinic staff that I am fluent in Spanish. I had heard of this phenomenon from bilingual colleagues in the past, but I was unprepared for the way my calendar had become inundated with "Spanish only" visits. The first couple of weeks were frustrating: it took time to schedule ultrasounds for patients who did not speak enough English to do so themselves. It took effort to think in Spanish while charting in English. It took work to translate all the discharge instructions normally stored as easy-to-use English-language templates into their Spanish equivalents.

Moreover, ours is a teaching hospital, and having the medical students join us is one of the most enjoyable parts of clinic. When I was in the 
office, those not fluent in Spanish could work with me and observe a string of foreign-language visits occasionally punctuated with bursts of explanation-or they could work with the other residents. Most chose to work with the other residents.

Initially, I was annoyed at how long it took to see each patient and at how much of my day seemed to be consumed by nonmedical work. I was there to provide health care, I thought, not to fill out forms and schedule appointments. As I began to come to terms with my new routine, however, I noticed a gratifying pattern emerging, one that softened my frustration. I would often find that, when I walked into the room and began to speak in Spanish, the patient would give a sigh of relief, as if to say, "Oh, thank goodness! I won't have to work to communicate today." She would smile and ask where my odd accent was from (Nicaragua and Cuba), and then we would get down to the business at hand. The medicine I practiced was unchanged-I was still dealing with the same chief complaints as before, the same laboratory tests and counseling topics-but I realized that I was addressing a more fundamental need: the need to be understood.

Of course, this need is not unique to patients of limited English proficiency; all of us work to make our concerns heard in the doctor's office. But the issue becomes so much clearer when the patient is unsure whether her physician will even share her language. And the difficulty is not limited to the clinic: many of my patients cannot find their way around the hospital because they cannot read the signs. They are unable to schedule appointments because the operators do not speak Spanish. They have trouble navigating the city bus system and locating all the Medicaid papers the office requires. Some are undocumented and so face a constant fear of arrest and deportation.

This isolation takes an emotional toll on patients. It exacts a price I first became aware of very early in my medical career when I watched one of my mentors-call him Wilfredo Gonzalez-interview a woman who had just immigrated from Mexico and was utterly alone. When he asked earnestly how she was doing, her hard-won defenses seemed to crumple, and all of a sudden she was sitting on the exam table, sobbing. I watched, rapt, as Dr Gonzales-or Wilfredo, as he insisted I call him-reached out a steady hand to squeeze her shoulder and offered a tissue.

"This is my job: I make people cry," he said as we left the room. He didn't mean it in an unkind way. He meant that he saw it as one of the privileges of his job to elicit the patient's fears and struggles, to hear and to bear witness to the excitement and suffering of being a new immigrant. Much of my year with Wilfredo was spent helping such patients navigate the intricacies of this alien health system, translating medicine into their native tongue and advocating on their behalf with numerous state agencies and nonprofits.

Working with a predominantly Spanish-speaking population, both as a medical student and now as a resident, reminds me of the importance of understanding patients. I mean this not only in the literal sense of being able to understand the patient's language, but in the broader sense of having the courage to ask about the patient's struggles and to invest effort in helping her overcome them. Through practice and compassion, good physicians find ways to forge a common language with patients of disparate backgrounds: to become a doctor, then, is also to become an interpreter.

To read or post commentaries in response to this article, see it online at http://www.annfammed.org/content/12/5/473.

Submitted July 4, 2013; submitted, revised, November 18, 2013; accepted January 16, 2014.

Key words: interpretation; limited English proficiency; immigrant health 